\title{
Water use spatio-temporal mapping linked to hydraulic fracturing across the Eagle Ford Play, Texas (USA)
}

\section{Mapa de la variación espacio-temporal del uso del agua asociado al fracturamiento hidráulico en el Play Eagle Ford (EUA)}

\author{
Antonio Hernández-Espriú*a , Saúl Arciniega-Esparza ${ }^{\text {b,c }}$, Sergio Macías-Medrano ${ }^{\text {a }}$ \\ ${ }^{a}$ Hydrogeology Group, Faculty of Engineering, Universidad Nacional Autónoma de México, Mexico City, 04510, Mexico. \\ ${ }^{b}$ Institute of Engineering, Universidad Nacional Autónoma de México, Mexico City, 04510, Mexico. \\ ${ }^{c}$ Programa de Maestría y Doctorado en Ingeniería, Universidad Nacional Autónoma de México, Mexico City, 04510, Mexico.
}

\begin{abstract}
Massive development of unconventional resources using hydraulic fracturing (HF) procedures, has been carried out since the last three decades, with focus on Texas, USA, including the Eagle Ford (EF) play. International concerns have been raised regarding water and environmental impacts closely related to shale production. The aim of this paper is to map spatio-temporal trends of $\mathrm{HF}$ development (water use and well density) examining the entire production period in the EF. We used FracFocus as the main source of HF information, from 2009 to 2017. Our database managed in Python, SAGA GIS and QGIS, comprised 15,013 oil and gas well records. Statistical results show that median HF water use has been progressively increasing over time, from $\sim 18,000 \mathrm{~m}^{3} / \mathrm{well}$ (2010) to $\sim 38,000 \mathrm{~m}^{3} /$ well (2017). Mapping results illustrate that both well density and HF water use peaked in 2014, whereas the area required for HF encompassed $\sim 16,800 \mathrm{~km}^{2}$ or $\sim 70 \%$ of the play surface area. We summarize our results in a public domain dynamic GIS-based digital map.
\end{abstract}

Keywords: Shale gas; play; water-energy; hydraulic fracturing; Eagle Ford; GIS

\section{Resumen}

El desarrollo masivo de recursos no convencionales de gas y aceite usando fracturamiento hidráulico (FH) se ha llevado a cabo desde hace tres décadas, con especial atención en Texas, EUA, incluida la Formación Eagle Ford (EF). Por lo anterior, se han generado alarmas internacionales debido a los grandes volúmenes de agua e impactos ambientales relacionados con la extracción de gas y aceite en lutitas. El objetivo de este artículo es cartografiar la tendencia espacio-temporal de los consumos de agua y la densidad de pozos asociada al FH considerando todo el período de producción de la EF. Usamos FracFocus como la principal fuente de información de 2009-2017. La base de datos manipulada en Python, SAGA GIS y QGIS constó de 15,013 registros de pozos de gas y aceite. Los resultados estadísticos muestran que la mediana de los consumos para FH se ha incrementado progresivamente con respecto al tiempo, de $\sim 18,000 \mathrm{~m}^{3} /$ pozo (2010) a $\sim 38,000 \mathrm{~m}^{3} /$ pozo (2017). Los resultados de la cartografía ilustran que el pico de la densidad de pozos y consumos de agua ocurrió en el 2014, mientras que el desarrollo espacial del FH cubrió $\sim 16,800 \mathrm{~km}^{2}$ o $\sim 70 \%$ del área superficial del play. Los resultados se presentan en un mapa dinámico disponible al público en formato SIG.

Palabras clave: Gas en lutitas; agua-energía; fracturamiento hidráulico; Eagle Ford; GIS

(c) A. Hernández-Espriú, S. Arciniega-Esparza, S. Macías-Medrano This is an Open Access article distributed under the terms of the Creative Commons Attribution License (https://creativecommons.org/licenses/by-nc-sa/4.0/), which permits non-commencial sharing of the work and adaptions, provided the original work is properly cited and the new creations are licensed under identical terms.

*E-mail address: ahespriu@unam.mx; ahespriu@gmail.com

\section{Introduction}

Hydraulic fracturing (HF), also known as hydrofracturing or fracking, has become the standard procedure to develop hydrocarbon unconventional resources stored in clayey-based low permeability reservoirs (Ikonnikova et al., 2016). Hydraulicrelated operations have allowed profitable extraction of gas and liquid oil from shale and tight formations that four decades ago 
was nearly impossible to achieve. Novel advances in horizontal drilling and HF stages have transformed the oil industry leading to a new energy era: the shale revolution (Hughes, 2013). HF involves the injection of a pressurized fluid composed by large volumes of water ( $90 \%)$, sand and man-made chemical additives. Thus, international concerns have been raised regarding water and environmental impacts closely related to shale production, including surface and groundwater withdrawals, aquifer pollution, baseflow decrease, air quality degradation, induced seismicity during produced water disposal, landscape fragmentation, changes in land use, threats to biota or human health risks, among others (Arciniega-Esparza et al., 2017; Barcelo and Bennett, 2016; Brittingham et al., 2014; Clancy et al., 2018; Entrekin et al., 2018; Kim and Lu, 2018; Kondash et al., 2017; Lee et al., 2016; Nicot et al., 2014; Rutqvist et al., 2013; Slonecker et al., 2012; Wolaver et al., 2018).

Large-scale expansion of shale gas/oil in Texas has been carried out since $\sim 1990$ with the development of the Barnett play (central Texas), the main producer worldwide in the 2000s, accounting for $\sim 66 \%$ of shale gas production in the US from 2007-2009 (Nicot and Scanlon, 2012). In Texas alone, 40,521 unconventional wells were drilled from 2008-2014 across the major plays (Barnett, Eagle Ford, Haynesville and the Permian Basin), which totaled $\sim 457$ million $\mathrm{m}^{3}\left(\mathrm{Mm}^{3}\right)$ of water (Chen and Carter, 2016) to satisfy HF procedures, i.e., HF water use.

The Eagle Ford play $\left(\sim 24,000 \mathrm{~km}^{2}\right)$ in central-south Texas, which correlates with Cretaceous formations in northeast Mexico within the Sabinas and Burgos basins, is a young play. Production began in 2009 and currently totaled $~ 15,000$ unconventional wells producing over 1 million barrels/day (EIA, 2017). From 2009-2013, net water use accounted for $150 \mathrm{Mm}^{3}$ to satisfy 8,301 frac wells; mostly horizontals (Scanlon et al., 2014). During 2009 to mid-2011, median HF water use was 16,100 $\mathrm{m}^{3}$ /well (Nicot and Scanlon, 2012) whereas in 2016, this value increased by a two-fold; that is $\sim 33,000 \mathrm{~m}^{3} /$ well (Ikonnikova et al., 2017). See Hammes et al. (2014) for a comprehensive description of the geological and petrophysical details of the Eagle Ford play.

Recent research has revealed the key role of water management in the shale production chain, comprising horizontal drilling, hydrofracturing, flowback/recycling, produced water disposal and surface/groundwater monitoring. Overall, published literature discussing water footprint associated with the Eagle Ford play development (e.g. Hernández-Espriú, et al. 2019; Gallegos et al., 2015), reflect short periods of time (i.e., $2-5$ years) and thus, spatio-temporal trends of HF water use considering longer periods is comparative scarce (Kondash et al., 2018).

The aim of this paper is to map spatio-temporal trends of water use associated with the Eagle Ford Shale play development in Texas, examining the entire production period, from 2009 to 2017. In addition, we aimed at estimating representative water use values vs time, to inform further HF water use research in Mexico and other early-stage plays, worldwide, with similar conditions.

\section{Methods}

FracFocus Chemical Disclosure Registry Version 3.0 (https://fracfocus.org/) was used as the main source of information to depict spatio-temporal trends of HF water demand in the Eagle Ford play, evaluated from 01 January 2009 to 31 December 2017.

FracFocus is a freely database managed by the Groundwater Protection Council and the Interstate Oil and Gas Commission, which provides oil and gas information from the US and some parts of Canada, including fracturing start and end date, state, county, API number (API = American Petroleum Institute), operator name, well name, well latitude and longitude (NAD83 datum), true vertical depth, HF fluid composition expressed as Chemical Abstract Service (CAS) numbers, and the total base water volume. The latter was directly used as HF water consumption or water use to satisfy shale production per well.

A dataset comprising 15,013 wells were explored in Microsoft Excel to detect inconsistences (i.e., missing values, inaccurate units, etc). The modified dataset was then exported and managed using advanced mathematical tools such as Python (Python Core Team, 2015) by means of Pandas 0.20.3 (Mckinney and Team, 2015) and Seaborn 0.8.0 libraries (Waskom, 2017).

Spatio-temporal and statistical mapping analysis included: (1) well density (i.e., number of wells per surface area) and (2) $\mathrm{HF}$ water use evaluation. A $5 \times 5 \mathrm{~km}^{2}$ vector layer grid was defined covering the whole play extent, by using SAGA GIS (Conrad et al. 2015) and QGIS (QGIS Development Team, 2018) spatial tools. The grid size was established in order to improve the visual representation since spatial results in a $1 \times 1$ $\mathrm{km}^{2}$ grid were unreadable. Unconventional well counting per year (2009-20017) was carried out by means of the Module count points in polygons, in which FraFocus wells represent the HF wells and the square grid, previously created, embodies the polygon. Finally, well density (number of wells $/ \mathrm{km}^{2}$ ) was computed by dividing the number of wells/cell by the cell's total area $\left(25 \mathrm{~km}^{2}\right)$.

Furthermore, we estimated total water use per year (20092017), considering the sum of all wells/cell and the mean HF water use/well. No distinction was made between vertical and horizontal (e.g. laterals) wells, as this information is lacking in FracFocus.

The associated geographical information system and related maps were developed in QGIS. Plates 1 and 2 show the main mapping outcomes of this assessment. The dynamic version of the map can be visualized on the journal platform.

Finally, to show the significant impact of unconventional hydrocarbon exploitation on the landscape we have included two Landsat scenes in the dynamic map. We chose cloudless scenes acquired before and after the beginning of the exploitation by fracking of the Eagle Ford play. The initial scene is a Landsat 7 image acquired on 09-26-2002 and the final scene is a Landsat 8 acquired on 11-01-2018. The processing included RGB band combinations to enhance the well platforms, 
the fracking wastewaters pools and the xerophytic vegetation. We used bands 4, 3, and 2 for the Landsat 7 image and bands 5, 4 , and 3 for the Landsat 8 image. A panchromatic enhancement was also used.

\section{Results}

\subsection{Statistical results}

HF water use per well considering the production period from 2009-2017 is shown in Figure 1. As noted, water consumption/well has been progressively increasing over time, as pointed out by previous studies (Ikonnikova et al., 2017). The year 2009 was negligible for practical purposes, while total annual HF water use peaked to $\sim 100 \mathrm{Mm}^{3}$ in 2014 and since then declined (Figure 1), related to oil price decrease in 2015-2016 (EIA, 2019).

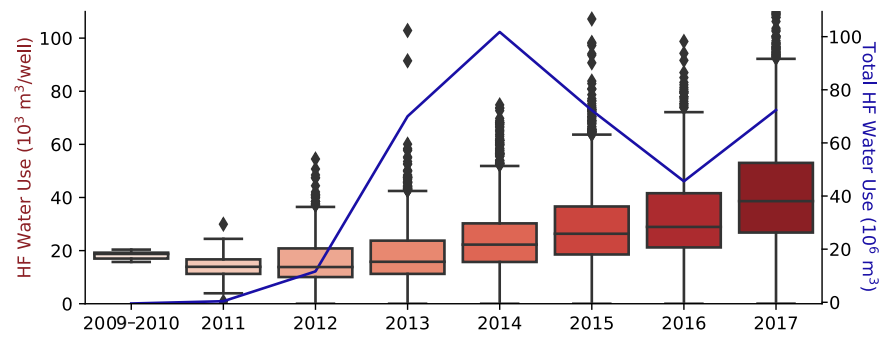

Figure 1. Boxplots showing temporal trends of hydraulic fracturing water use per well $\left(10^{3} \mathrm{~m}^{3}\right)$ and cumulative annual HF water use (blue line) over time (2009-2017). Diamonds refer to outlines.

Figura 1. Boxplots mostrando las tendencias temporales del uso de agua para fracturamiento hidráulico por pozo $\left(10^{3} \mathrm{~m}^{3}\right)$ y acumulado anual (línea azul) para el periodo analizado (2009-2017). Los valores atípicos se representan como diamantes.

In 2010 FracFocus registered only 5 frac wells using a mean HF water demand of $\sim 18,000 \mathrm{~m}^{3} /$ well. In contrast, four years later, drilling increased spectacularly to $\sim 4,300$ wells in 2014 demanding a mean volume of $\sim 23,600 \mathrm{~m}^{3} /$ well, equaled to an accumulated volume of $\sim 100 \mathrm{Mm}^{3}$, play-wide, for that particular year.

Since 2014, HF water volume decreased in 2015 and 2016 to $\sim 70$ and $46 \mathrm{Mm}^{3}$, respectively, and increased again to 70 $\mathrm{Mm}^{3}$ in 2017 (Figure 1). However, mean HF water use per well has been gradually growing to $\sim 28,500,31,800$ and 40,800 $\mathrm{m}^{3} /$ well for 2015, 2016 and 2017, respectively. Over the eightyear production period, HF water use ranged between 14,656$32,257 \mathrm{~m}^{3} /$ well $\left(25^{\text {th }}-75^{\text {th }}\right.$ percentiles), whereas in the most recent year (2017), HF water use fluctuated by 26,675-52,349 $\mathrm{m}^{3} /$ well $\left(25^{\text {th }}-75^{\text {th }}\right.$ percentiles $)$.

Overall, total water use associated with the Eagle Ford play development, totaled $392.73 \mathrm{Mm}^{3}$. That is, for instance, the total groundwater abstracted in the state of Morelos during 2015 to satisfy a dominant percentage of irrigation, industry and domestic supply (CONAGUA, 2016). Table 1 summarize these outcomes.

\subsection{Map synopsis}

Spatio-temporal mapping for the period 2009-2017 of unconventional well density in the Eagle Ford play, expressed as the number of unconventional wells per surface area (wells $/ \mathrm{km}^{2}$ ), is shown in Plate 1. Moreover, water use spatio-temporal mapping to satisfy HF production is displayed in Plate 2. Wells density and HF water use were classified into a five class maps, using a percentile-based rule to appreciate the statistical variation of the most critical development year (2014). The classes in both maps follow the same color classification to compare differences among both maps in terms of wells density and water use.

Plate 1 shown that well density peaked in 2014 with a mean value of $\sim 0.26$ wells $/ \mathrm{km}^{2}$, which represented a $\sim 70 \%$ of the total play surface area partially covered by unconventional wells in that year. In 2017, well density decreased to $\sim 0.21$ wells/ $\mathrm{km}^{2}$ covering only $\sim 33 \%$ of the play area. Over the whole production period, well density accounted for 0.16 well $/ \mathrm{km}^{2}$.

On the other hand, in concordance with the well density map (Plate 1), HF water use also peaked in 2014 with a median value of $\sim 22,500 \mathrm{~m}^{3} /$ well (Plate 2). Unconventional wells that were fractured in 2014 using $30,000-40,000 \mathrm{~m}^{3}$ of water, covered $\sim 9,100 \mathrm{~km}^{2}$ of the play (38\%), followed by wells using less than $15,000 \mathrm{~m}^{3}\left(3,400 \mathrm{~km}^{2}\right.$ or $14 \%$ of the play), or wells consuming $40,000-50,000 \mathrm{~m}^{3}\left(3,350 \mathrm{~km}^{2} ; 14 \%\right)$. Finally, fracturing wells with the largest water use $\left(>50,000 \mathrm{~m}^{3}\right)$ were distributed along $900 \mathrm{~km}^{2}$, which is only $\sim 3 \%$ of the play area. These figures suggest that HF development encompassed $\sim 16,800 \mathrm{~km}^{2}$ or $\sim 70 \%$ of the Eagle Ford play for 2014. In 2017, $\mathrm{HF}$ extension decreased by more than half, to about $\sim 8,000$ $\mathrm{km}^{2}$, or $\sim 33 \%$ of the play surface area.

\section{Conclusions}

We present a GIS-based, dynamic map showing spatio-temporal trends of water use and well development linked to hydraulic fracturing in the Eagle Ford play (Texas, USA). Here, we show spatio-temporal results at annual scale for the production period from 2009 to 2017 . For this, we used freely available data and open-source tools for managing, assessing and linking spatial information.

From the statistical analysis we concluded that median HF water use has been progressively increasing over time, from $\sim 18,000 \mathrm{~m}^{3} /$ well (2010) to $\sim 38,000 \mathrm{~m}^{3} /$ well (2017). On the other hand, spatio-temporal analysis showed that both well density (wells $/ \mathrm{km}^{2}$ ) and HF water use peaked in 2014, whereas HF development encompassed $\sim 16,800 \mathrm{~km}^{2}$, equivalent to $\sim 70 \%$ of the surface area, play-wide.

\section{Map design}

The map was configured in NAD83 projection (North American Datum 1983), using vector files developed by our research team, derived from FracFocus information. We used Python 
and SAGA GIS for managing and assessing spatial information, and QGIS for displaying the final plates, with the following features:

- Scale 1:3,000,000

- Total area of $260,333 \mathrm{~km}^{2}$

- Graticule spacing: $1^{\circ} 0^{\prime} 0 "$

\section{Acknowledgements}

The first author acknowledges financial support provided by the COMEXUS Fulbright García Robles Fellowship, the UNAM-DGAPA PASPA and the Matías-Romero (SRE-LLILAS UT) Research Visiting Programs that supported this research. Also, to Scott Tinker, Bridget Scanlon, Michael H. Young, Brad Wolaver, JP Nicot and Robert Reedy of the Bureau of Economic Geology (The University of Texas at Austin) for the hospitality during the sabbatical leave of A. Hernández-Espriú. The authors are grateful for the constructive comments of Daniel Itzamna Avila Ortega and one anonymous reviewer that greatly improved the scientific quality of the manuscript. We would also like to thank Luis Felipe Ruiz Castañeda and Francisco Javier Osorno Covarrubias for the dynamic map development and implementation. Special thanks go to Javier Osorno for its contribution to the Landsat image processing. This is the 12th contribution from the Hydrogeology Group (Earth Sciences Division), Faculty of Engineering, UNAM, Mexico.

\section{References}

Arciniega-Esparza, S., Breña-Naranjo, J. A., Hernández-Espriú, A., PedrozoAcuña, A., Scanlon, B. R., Nicot, J. P., Young, M. H., Wolaver, B. D., Alcocer-Yamanaka, V. H., 2017. Baseflow recession analysis in a large shale play: Climate variability and anthropogenic alterations mask effects of hydraulic fracturing. Journal of Hydrology 553, 160-171, https://doi.org/10.1016/j.jhydrol.2017.07.059.

Barcelo, D., Bennett, J. P., 2016. Human health and environmental risks of unconventional shale gas hydrofracking. Science of The Total Environment 544, 1139-1140, https://doi.org/10.1016/j.scitotenv.2015.12.045.
Brittingham, M. C., Maloney, K. O., Farag, A. M., Harper, D. D., Bowen, Z. H., 2014. Ecological Risks of Shale Oil and Gas Development to Wildlife, Aquatic Resources and their Habitats. Environmental Science \& Technology 48 (19), 11034-11047, https://doi.org/10.1021/es5020482.

Chen, H., Carter, K. E., 2016. Water usage for natural gas production through hydraulic fracturing in the United States from 2008 to 2014. Journal of Environmental Management 170, 152-159, https://doi.org/10.1016/j.jenvman.2016.01.023.

Clancy, S. A., Worrall, F., Davies, R. J., Gluyas, J. G., 2018. An assessment of the footprint and carrying capacity of oil and gas well sites: The implications for limiting hydrocarbon reserves. Science of The Total Environment 618, 586-594, https://doi.org/10.1016/j.scitotenv.2017.02.160.

CONAGUA, 2016. Estadísticas del Agua en México, Edición 2016 [www document]. http://sina.conagua.gob.mx/publicaciones/EAM_2016.pdf (accessed 4.7.19).

Conrad, O., Bechtel, B., Bock, M., Dietrich, H., Fischer, E., Gerlitz, L., Wehberg, J., Wichmann, V., Böhner, J., 2015. System for Automated Geoscientific Analyses (SAGA) v. 2.1.4. Geoscientific Model Development 8 (7), 1991-2007, https://doi.org/10.5194/gmd-8-1991-2015.

EIA, 2017. Annual Energy Outlook 2017 with projections to 2050 [www document]. https://www.eia.gov/outlooks/archive/aeo17/ (accessed 4.7.19).

EIA, 2019. Short-Term Energy Outlook [www document]. https://www.eia.gov/outlooks/steo/report/prices.php (accessed 2.13.19).

Entrekin, S., Trainor, A., Saiers, J., Patterson, L., Maloney, K., Fargione, J., Kiesecker, J., Baruch-Mordo, S., Konschnik, K., Wiseman, H., Nicot, J.P., Ryan, J. N., 2018. Water Stress from High-Volume Hydraulic Fracturing Potentially Threatens Aquatic Biodiversity and Ecosystem Services in Arkansas, United States. Environmental Science \& Technology 52 (4), 2349-2358, https://doi.org/10.1021/acs.est.7b03304.

Gallegos, T. J., Varela, B. A., Haines, S. S., Engle, M. A., 2015. Hydraulic fracturing water use variability in the United States and potential environmental implications. Water Resources Research 51 (7), 5839-5845, https://doi.org/10.1002/2015WR017278.

Hammes, U., Eastwood, R., McDaid, G., Vankov, E., Gherabati, S. A., Smye, K., Shultz, J., Potter, E., Ikonnikova, S., Tinker, S., 2016. Regional assessment of the Eagle Ford Group of South Texas, USA: Insights from lithology, pore volume, water saturation, organic richness, and productivity correlations. Interpretation 4 (1), SC125-SC150, https://doi.org/10.1190/INT2015-0099.1

Hernández-Espriú, A., Wolaver, B., Arciniega-Esparza, S., Scanlon, B. R., Young, M. H., Nicot, J.-P., Macías-Medrano, S., Breña-Naranjo, J. A., 2019. A screening approach to improve water management practices in undeveloped shale plays, with application to the transboundary Eagle Ford Formation in northeast Mexico. Journal of Environmental Management 236, 146162, https://doi.org/10.1016/j.jenvman.2018.11.123.

Hughes, J. D., 2013. A reality check on the shale revolution. Nature 494, $307-$ 308, https://doi.org/10.1038/494307a.

Ikonnikova, S., Vankov, E., Gülen, G., Browning, J., 2016. Understanding Shale Resource Production: What are the Key Variables ? Society of

Table 1: Hydraulic fracturing water use in the Eagle Ford play over the production period 2009-2017.

Tabla 1: Uso de agua para fracturamiento hidráulico en el play Eagle Ford para el periodo de producción 2009-2017.

Hydraulic fracturing water use per well $\left(\mathrm{m}^{3}\right)$

\begin{tabular}{|c|c|c|c|c|c|c|c|c|c|}
\hline $2009-2010$ & 5 & 15728.86 & 18215.48 & 17001.18 & 18739.00 & 19227.46 & 20380.90 & 1846.96 & 0.091 \\
\hline 2011 & 69 & 60.57 & 13746.21 & 11236.42 & 13902.57 & 16699.17 & 29944.35 & 5235.95 & 0.948 \\
\hline 2013 & 4117 & 0.00 & 17113.88 & 11237.78 & 15789.34 & 23749.79 & 91457.56 & 10145.07 & 70.561 \\
\hline 2014 & 4311 & 0.00 & 23651.17 & 15725.12 & 22251.37 & 30243.90 & 74852.30 & 11296.65 & 102.305 \\
\hline 2015 & 2548 & 0.00 & 28537.74 & 18536.54 & 26346.45 & 36582.28 & 98365.12 & 14458.97 & 72.821 \\
\hline 2009-2017 & 15013 & 0.00 & 24960.84 & 14656.93 & 22639.00 & 32257.87 & 99042.58 & 15163.49 & 392.73 \\
\hline
\end{tabular}


Petroleum Engineers, https://doi.org/10.2118/179984-MS.

Ikonnikova, S. A., Male, F., Scanlon, B. R., Reedy, R. C., McDaid, G., 2017. Projecting the Water Footprint Associated with Shale Resource Production: Eagle Ford Shale Case Study. Environmental Science \& Technology 51 (24), 14453-14461, https://doi.org/10.1021/acs.est.7b03150.

Kim, J.-W., Lu, Z., 2018. Association between localized geohazards in West Texas and human activities, recognized by Sentinel-1a/B satellite radar imagery. Scientific Reports 8 (1), 4727, https://doi.org/10.1038/s41598-01823143-6

Kondash, A. J., Albright, E., Vengosh, A., 2017. Quantity of flowback and produced waters from unconventional oil and gas exploration. Science of The Total Environment 574, 314-321, https://doi.org/10.1016/j.scitotenv.2016.09.069.

Kondash, A. J., Lauer, N. E., Vengosh, A., 2018. The intensification of the water footprint of hydraulic fracturing. Science Advances 4 (8), https://doi.org/10.1126/sciadv.aar5982.

Lee, J.-Y., Weingarten, M., Ge, S., 2016. Induced seismicity: the potential hazard from shale gas development and $\mathrm{CO} 2$ geologic storage. Geosciences Journal 20 (1), 137-148, https://doi.org/10.1007/s12303-015-0030-5.

Nicot, J.-P., Scanlon, B. R., 2012. Water Use for Shale-Gas Production in Texas, U.S. Environmental Science \& Technology 46 (6), 3580-3586, https://doi.org/10.1021/es204602t.

Nicot, J.-P., Scanlon, B. R., Reedy, R. C., Costley, R. A., 2014. Source and Fate of Hydraulic Fracturing Water in the Barnett Shale: A Historical Perspective. Environmental Science \& Technology 48 (4), 2464-2471, https://doi.org/10.1021/es404050r.

QGIS Development Team, 2018. QGIS User Guide: Release 2.18.

Rutqvist, J., Rinaldi, A. P., Cappa, F., Moridis, G. J., 2013. Modeling of fault reactivation and induced seismicity during hydraulic fracturing of shalegas reservoirs. Journal of Petroleum Science and Engineering 107, 31-44, https://doi.org/10.1016/j.petrol.2013.04.023.

Scanlon, B. R., Reedy, R. C., Nicot, J. P., 2014. Will water scarcity in semiarid regions limit hydraulic fracturing of shale plays? Environmental Research Letters 9 (12), 124011, https://doi.org/10.1088/1748-9326/9/12/124011.

Slonecker, E., Milheim, L., Roig-Silva, C., Malizia, A., Marr, D., Fisher, G., 2012. Landscape consequences of natural gas extraction in Bradford and Washington Counties, Pennsylvania, 2004-2010. USGS Numbered Series 2012-1154, U.S. Geological Survey, Reston, VA, https://doi.org/10.3133/ofr20121154.

Wolaver, B. D., Pierre, J. P., Labay, B. J., LaDuc, T. J., Duran, C. M., Ryberg, W. A., Hibbitts, T. J., 2018. An approach for evaluating changes in landuse from energy sprawl and other anthropogenic activities with implications for biotic resource management. Environmental Earth Sciences 77 (5), 171 , https://doi.org/10.1007/s12665-018-7323-8.

This article accompanies the following material:

HTML:

DOI: $10.22201 /$ igg.25940694.2019.1.59.125

Static map:

DOI: 10.22201/igg.25940694.2019.1.59.126

Dynamic map:

DOI: 10.22201/igg.25940694.2019.1.59.127 
Well density spatio-temporal mapping linked to hydraulic fracturing across the Eagle Ford Play, Texas (USA)

Antonio Hernández-Espriú1, Saúl Arciniega-Esparza², Sergio Macías-Medrano

${ }^{1}$ Hydrogeology Group, Faculty of Engineering, Universidad Nacional Autónoma de México, Mexico City, 04510, Mexico.

Programa de Maestría y Doctorado en Ingeniería, Universidad Nacional Autónoma de México, Mexico City, 04510, Mexico.
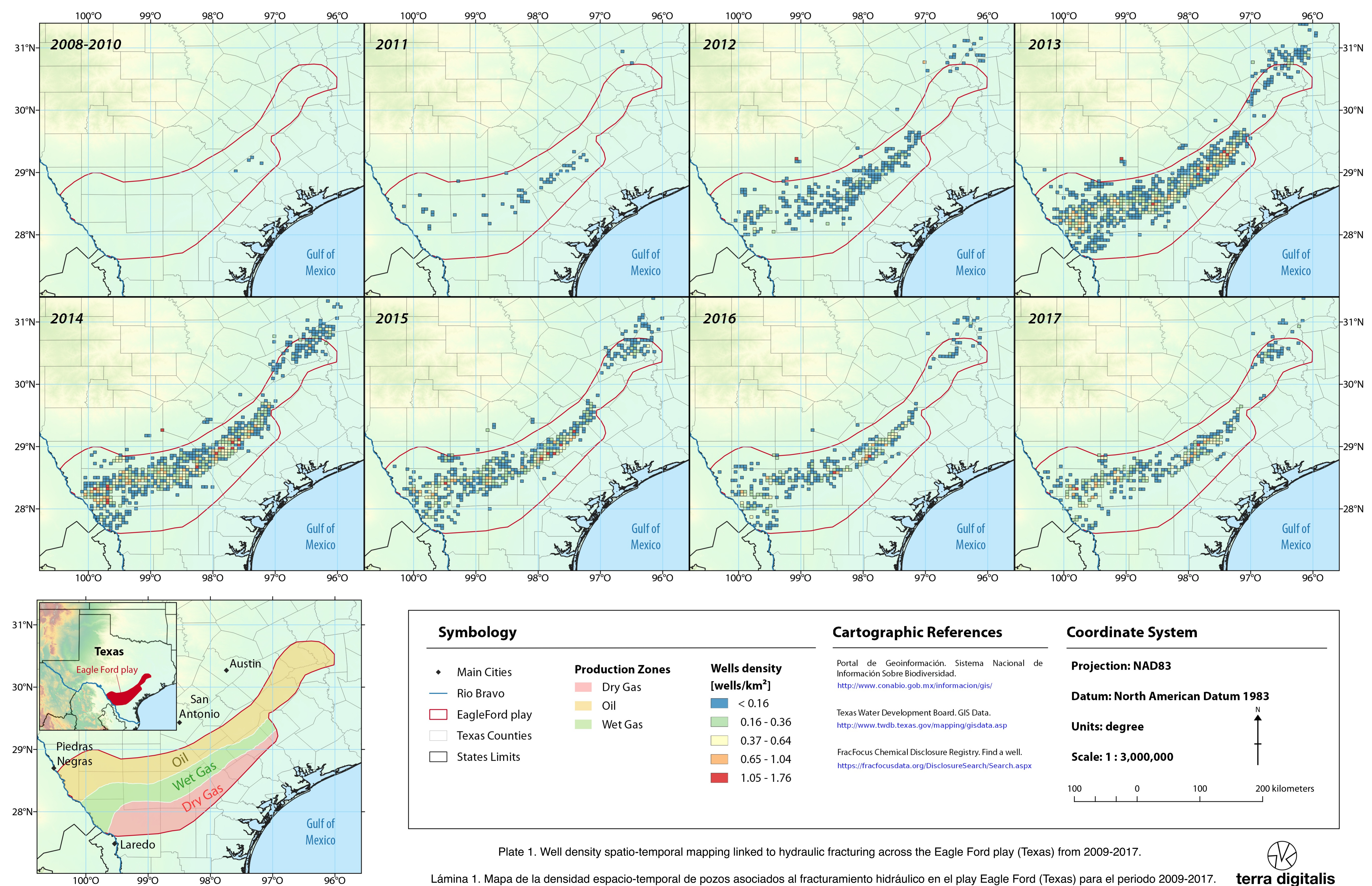

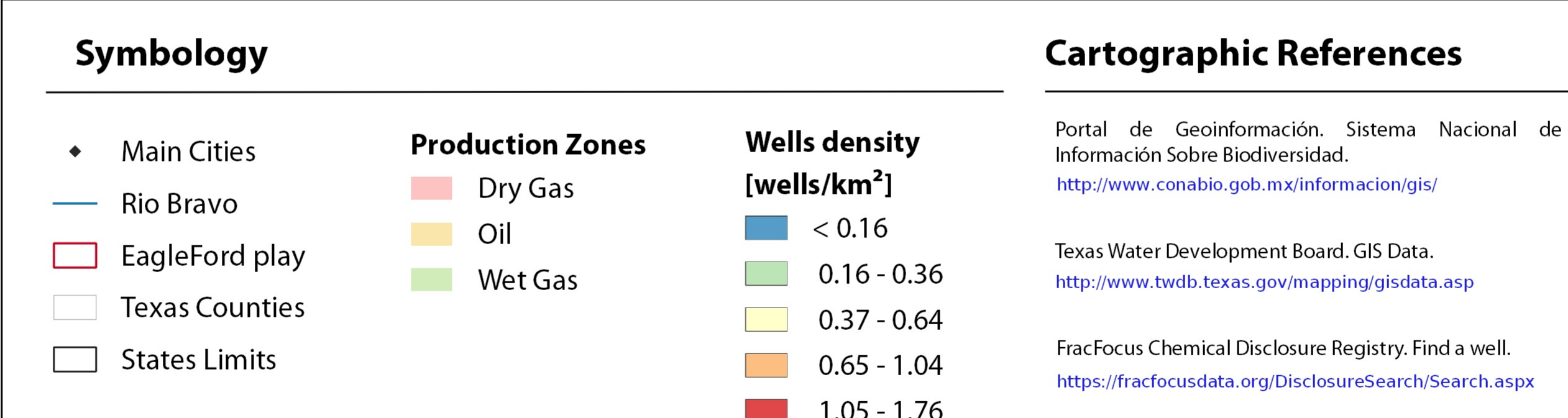

\section{Coordinate System}

Projection: NAD83

Datum: North American Datum 1983

Units: degree

Scale: $1: 3,000,000$

$100 \quad 100$

Plate 1. Well density spatio-temporal mapping linked to hydraulic fracturing across the Eagle Ford play (Texas) from 2009-2017. 


\section{Water use spatio-temporal mapping linked to hydraulic fracturing across the Eagle Ford Play, Texas (USA)}

Antonio Hernández-Espriú1, Saúl Arciniega-Esparza², Sergio Macías-Medrano

${ }^{1}$ Hydrogeology Group, Faculty of Engineering, Universidad Nacional Autónoma de México, Mexico City, 04510, Mexico.

Programa de Maestría y Doctorado en Ingeniería, Universidad Nacional Autonoma de México, Mexico City, 04510, Mexico.
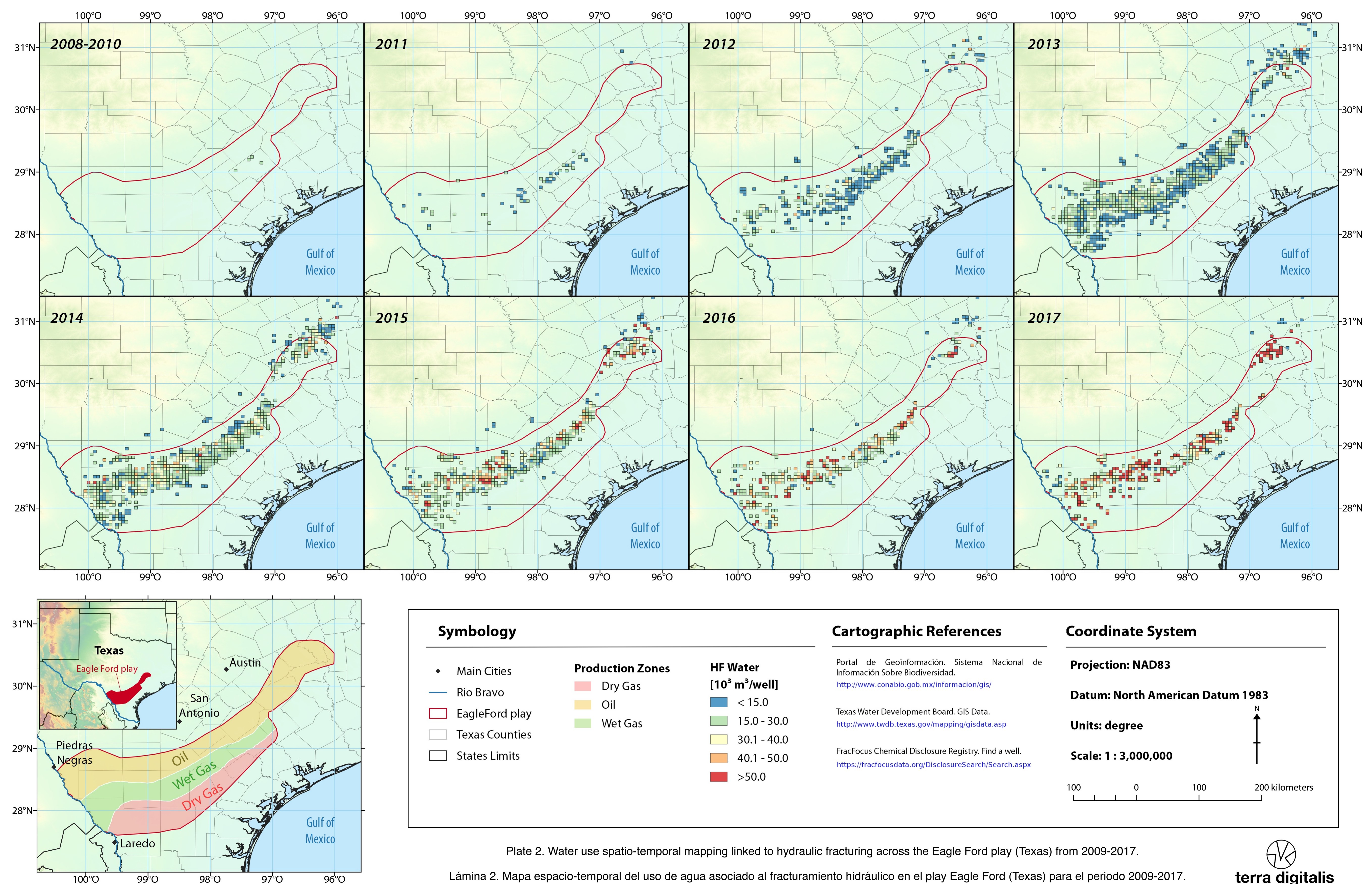

\begin{tabular}{|c|c|c|c|}
\hline \multicolumn{3}{|l|}{ Symbology } & Cartographic References \\
\hline - Main Cities & Production Zones & HF Water & $\begin{array}{l}\text { Portal de Geoinformación. Sistema Nacional de } \\
\text { Información Sobre Biodiversidad. }\end{array}$ \\
\hline — Rio Bravo & Dry Gas & {$\left[10^{3} \mathrm{~m}^{3} /\right.$ well] } & http://www.conabio.gob.m×/informacion/gis/ \\
\hline$\square$ EagleFord play & Oil & $\square<15.0$ & Texas Water Develonment Board GIS Data \\
\hline Texas Counties & Wet Gas & $\square \quad 15.0-30.0$ & http://www.twdb.texas.gov/mapping/gisdata.asp \\
\hline$\square$ States Limits & & $\begin{array}{r}30.1-40.0 \\
401-500\end{array}$ & FracFocus Chemical Disclosure Registry. Find a well. \\
\hline & & - 500 & orglDisclosuresearch/Search.aspx \\
\hline
\end{tabular}

\section{Coordinate System}

Projection: NAD83

Datum: North American Datum 1983

Units: degree

Scale: $1: 3,000,000$

$100 \quad 0 \quad 100$ 